\title{
Grosulár a diopsid v kryštalických vápencoch z lokality Čučma - Čierna baňa (Slovenská republika)
}

\author{
Grossular and diopside in crystalline limestone from the locality Čučma - Čierna baňa \\ (Slovak Republic)
}

\author{
Peter RužIČKa ${ }^{1) *}$, Peter Bačík $^{1)}$, Pavol Myšl'an ${ }^{1)}$ a Sergil Kurylo ${ }^{2)}$ \\ 1)Katedra mineralógie a petrológie, Prírodovedecká fakulta, Univerzita Komenského v Bratislave, Ilkovičova 6, \\ Mlynská dolina, 84215 Bratislava, Slovenská republika; *e-mail: peter.ruzicka@uniba.sk \\ 2)Ústav vied o Zemi, Slovenská akadémia vied, Ďumbierska 1, 97411 Banská Bystrica, Slovenská republika
}

RuŽIČKA P, BAČík P, MYŠL'AN P, KuRYLo S (2020) Grosulár a diopsid v kryštalických vápencoch z lokality Čučma - Čierna baňa (Slovenská republika). Bull Mineral Petrolog 28(1): 94-104 ISSN 2570-7337

\begin{abstract}
The identified mineral association in the crystalline limestones from the manganese locality Čučma - Čierna baňa consists of garnets and pyroxenes. Mineralogical composition of the samples Ču-1 and Ču-2 is represented by zonal garnets with $\mathrm{Grs}_{76.12-82.31}$; $\mathrm{Adr}_{17.69-23.88}$ composition in the core and $\mathrm{Grs}_{95.48-97.05}$; $\mathrm{Adr}_{2.95-4.52}$ composition in the rim. In the sample Ču-3 inverse zonality (the core $\mathrm{Adr}_{3.99}, \mathrm{Grs}_{96.01}$; the $\operatorname{rim} \mathrm{Adr}_{20.55}, \mathrm{Grs}_{79.45}$ ) of garnet is observable. The analyzed pyroxenes have a diopside composition with a variable $\mathrm{Mg} /\left(\mathrm{Mg}+\mathrm{Fe}^{2+}\right)$ ratio. A slightly increased content of $\mathrm{Mn}$ (up to $0.09 \mathrm{apfu}$ ) ascends into the johannsenite molecule.
\end{abstract}

Key words: Grossular, diopside, crystalline limestone, Čučma - Čierna baňa, Slovak Republic

Obdrženo 29. 3. 2020; prijato 11. 5. 2020

\section{Úvod}

Článok prináša nové informácie doplňujúce a zároveň prehodnocujúce poznatky o rôznorodosti minerálneho zloženia kryštalických vápencov, ktoré pochádzajú z historicky známeho mangánového výskytu Čučma - Čierna baňa. V kryštalických vápencoch sme prvý krát identifikovali granát prevažne grosulárového zloženia a diopsid. Okrem granátov a pyroxénov sa analyticky nepotvrdila prítomnost' d'alších silikátových fáz v skúmaných vzorkách. V článku stručne opisujeme poznatky súvisiace s geologickým a genetickým vývojom skúmanej oblasti v kontexte mangánovej mineralizácie, ktorej súčast'ou sú kryštalické vápence.

\section{Lokalizácia}

Podl'a geomorfologického členenia Slovenskej republiky (Mazúr, Lukniš 1980) lokalita Čučma - Čierna baňa patrí do oblasti Slovenského rudohoria a celku Volovské vrchy. Poloha lokality zodpovedá $48^{\circ} 42.703^{\prime}$ severnej šírky a $20^{\circ} 33.437^{\prime}$ východnej dížky s nadmorskou výškou $614 \mathrm{~m}$. Odobraté vzorky kryštalických vápencov pochádzajú z haldového materiálu, ktorý zostal po t’ažbe mangánových rúd. Mangánový výskyt známy pod názvom Čierna baňa $v$ banských poliach Ján, Laurent a Malvína (Maderspach 1880; Tóth 1882; Schafarzik 1904; Eisele 1907; Papp 1915) je vzdialený cca 2 km ssv. od obce Čučma na západnom svahu Strednej hory (Grecula et al. 1995).

\section{Geologická a mineralogicko-petrologická cha- rakteristika}

Šošovky kryštalických vápencov v skúmanej oblasti sú súčast'ou rytmicky sa striedajúcej staropaleozoickej flyšovej megasekvencie gelnickej skupiny južného gemerika spolu s lokálne vyvinutými polohami lyditov, bazaltových metavulkanoklastík a okolitých prevažne sludnato-grafitických fylitov (obr. 2). V zmysle litostratigrafického členenia podl'a Bajaníka et al. (1983, 1984) skúmaná lokalita patrí do vlachovského súvrstvia gelnickej skupiny a podla členenia Greculu (1982), respektíve Grecula et al. (1995, 2009, 2011) do holeckých vrstiev betliarskeho súvrstvia voloveckej superskupiny, ktorá v sebe spája pôvodne vyčlenené skupiny južného (gelnická skupina) a severného gemerika (rakovecká a klátovská skupina).

Stratigrafický rozsah gelnickej skupiny vrchné kambrium - spodný devón bol stanovený biostratigrafickými metódami (Snopková, Snopko 1979; Ivanička et al. 1989; Vozárová et al. 1998, 1999; Soták et al. 1999, 2000) a geochronologickými metódami (Putiš et al. 2008; Vozárová et al. 2010, 2016). Priemerné veky zirkónov z acídnych metavulkanitov vlachovského súvrstvia dosahujú hodnotu $494 \pm 1.6 \mathrm{Ma}$ (Vozárová et al. 2010). Staropaleozoický vývoj gemerika je považovaný za riftogénny (Grecula 1982; Grecula et al. 1995, 2011; Grecula, Radvanec 2005; Radvanec, Grecula 2016).

Horniny gelnickej skupiny sa sformovali účinkami regionálnej variskej a alpínskej metamorfózy v podmienkach fácie zelených bridlíc (Faryad 1991, 1995, 1997; Sassi, 

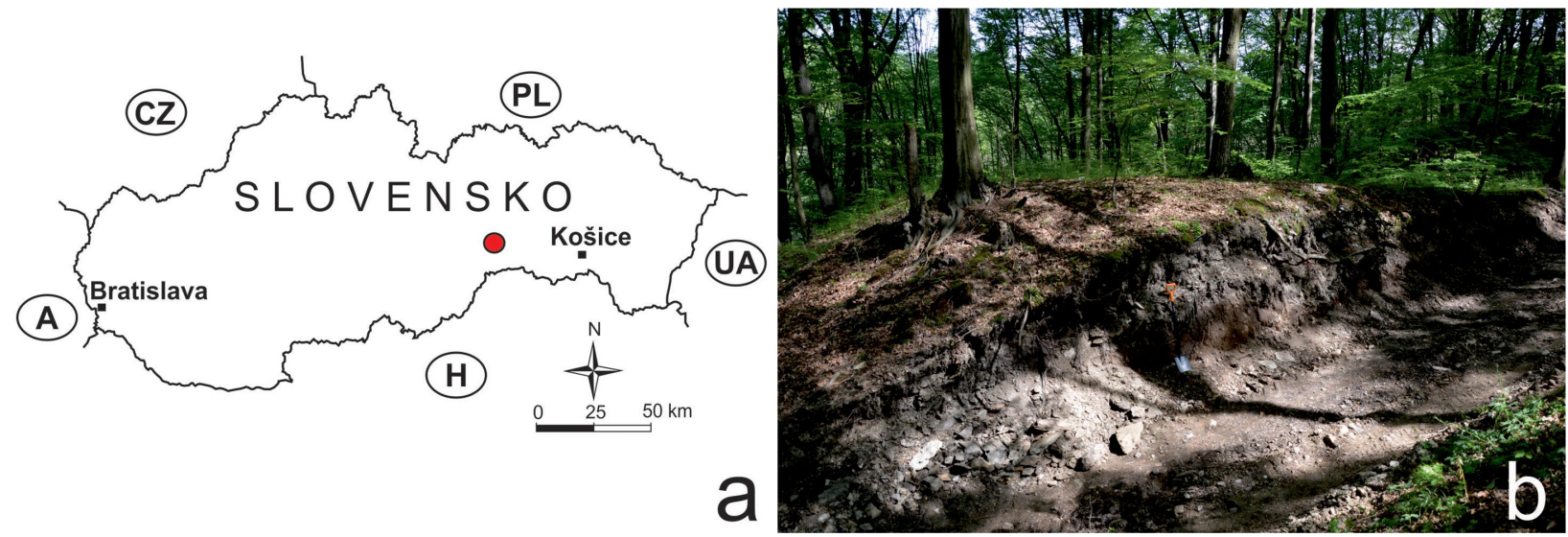

Obr. 1 Lokalizácia skúmaného územia: a) v mape Slovenskej republiky; b) pohl'ad na zárez haldy v blizkosti turistického chodníka smerujúceho z Čučmy na Skalisko - Volovec. Foto P. Ružička, 2016.

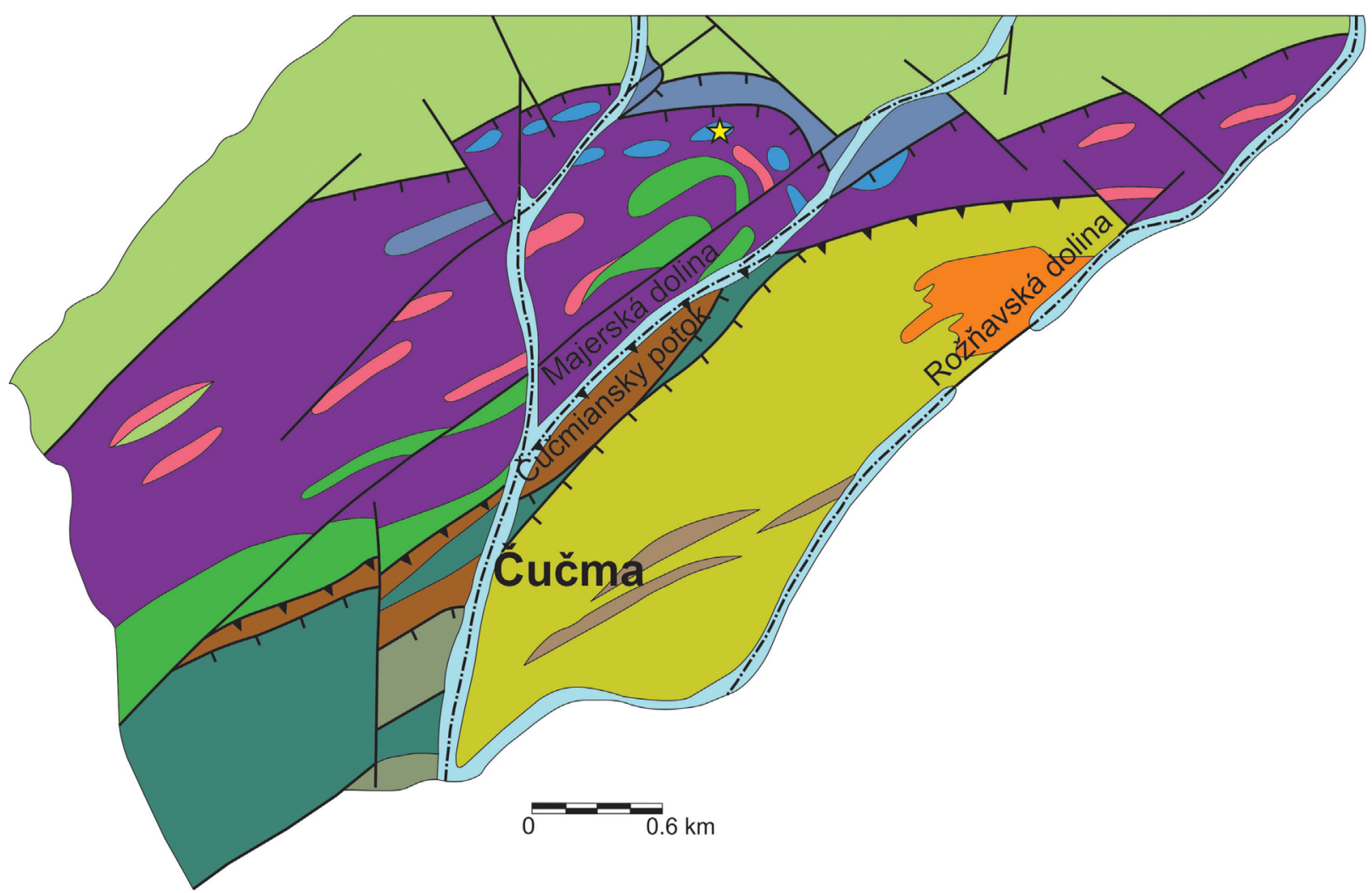

\section{Gelnická skupina gemerika}

\begin{tabular}{|c|c|c|}
\hline Chloriticko-muskoviticko-kremité fylity & & \\
\hline Biotiticko-muskovitické fylity a kvarcity & & \\
\hline $\begin{array}{l}\text { Biotiticko-muskovitické fylity s polohami } \\
\text { metapieskovcov a kvarcitov }\end{array}$ & & 3 \\
\hline $\begin{array}{l}\text { Metapieskovce až kvarcity s vložkami } \\
\text { chloriticko-muskovitických fylitov }\end{array}$ & & \\
\hline $\begin{array}{l}\text { Polohy grafiticko-chloriticko-muskovitických } \\
\text { fylitov v metapieskovcoch }\end{array}$ & & \\
\hline $\begin{array}{l}\text { Metapieskovce s vložkami ryolitových } \\
\text { metapyroklastík a grafiticko-chloriticko-muskovitických fylitov }\end{array}$ & & \\
\hline $\begin{array}{l}\text { Metapieskovce s vložkami ryolitových } \\
\text { metapyroklastík a chloriticko-muskovitických fylitov }\end{array}$ & & \\
\hline
\end{tabular}

Kvarcity, metapieskovce, ryolitové a bazaltové metapyroklastiká

Grafiticko-muskovitické fylity, vložky lyditov, karbonátov, metavulkanitov a metapieskovcov

Kryštalické vápence s lokalizačným bodom skúmaných vzoriek

Grafiticko-chloriticko-muskovitické fylity s vložkami lyditov, karbonátov a metavulkanitov

Chloriticko-grafiticko-muskovitické porfyroidy

Fluviálne sedimenty

(kvartér)

metapyroklastík a chloriticko-muskovitických fylitov

Tektonika:

a) príkrovové línie; b) zlomy; c) prešmyky

Obr. 2 Zjednodušená geologická mapa skúmaného územia modifikovaná podl’a Greculu et al. (2009). 
Vozárová 1987, 1992; Mazzoli, Vozárová 1989; Vozárová 1993, 1998). Na lokalite Čučma - Čierna baňa bol aplikovaný rodonitovo-pyroxmangitový geotermometer podla Schultz-Güttler a Peters (1987) pre stanovenie podmienok metamorfózy mangánových sedimentov. Metamorfó-

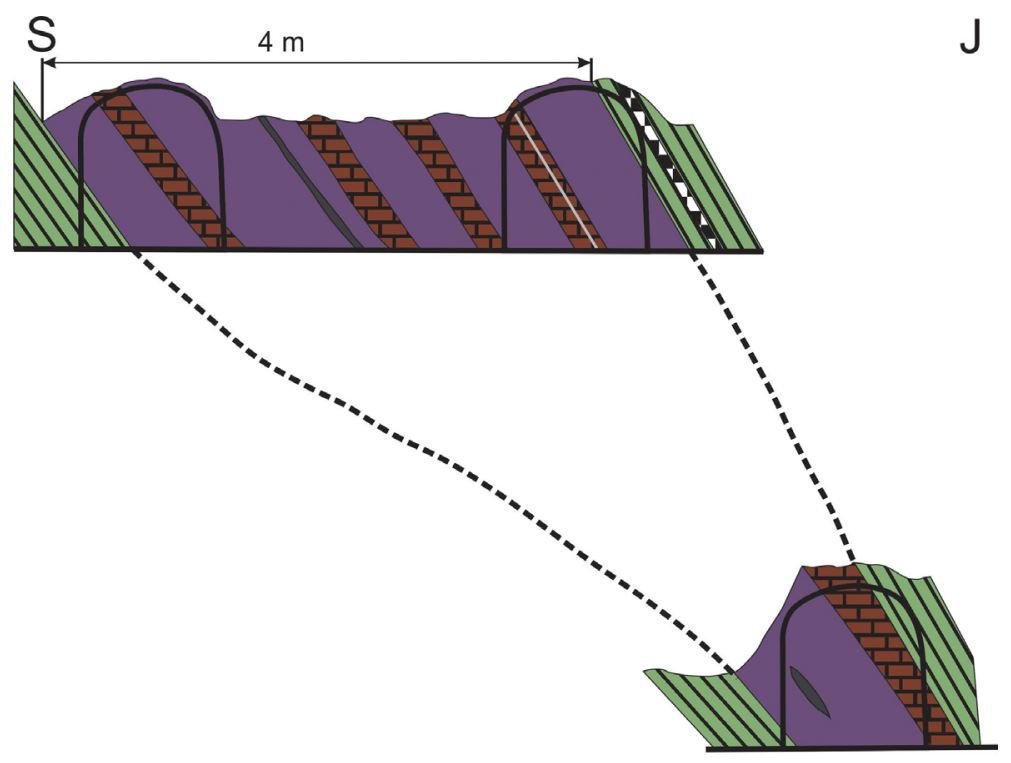

Sludnato-grafitické fylity
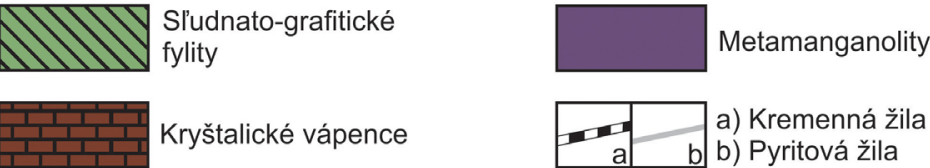

Kryštalické vápence

Magnetitová poloha

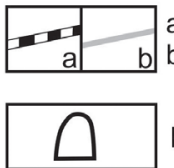

a) Kremenná žila

b) Pyritová žila

Banské štôlne

Obr. 3 Geologický profil medzi hornou a dolnou mangánovou štôlňou (Schafarzik 1904).

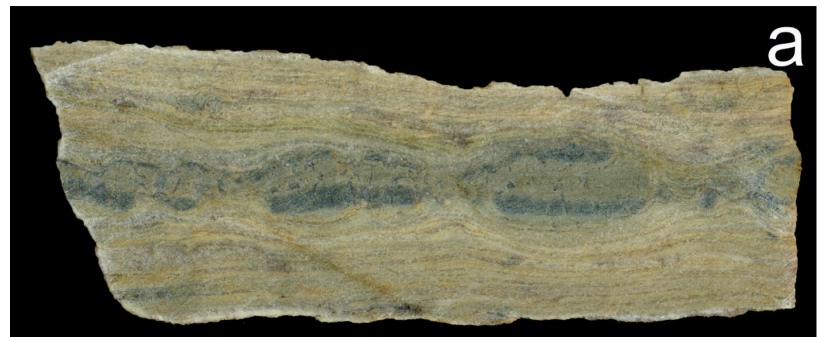

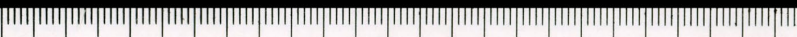
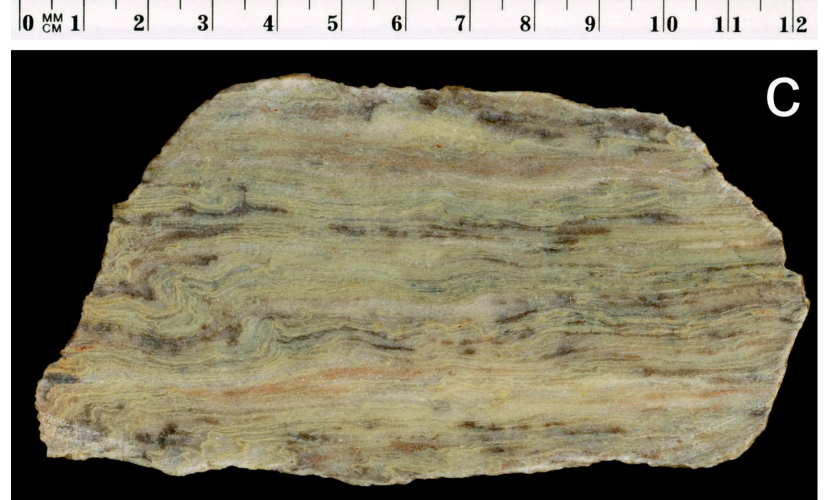

|III|
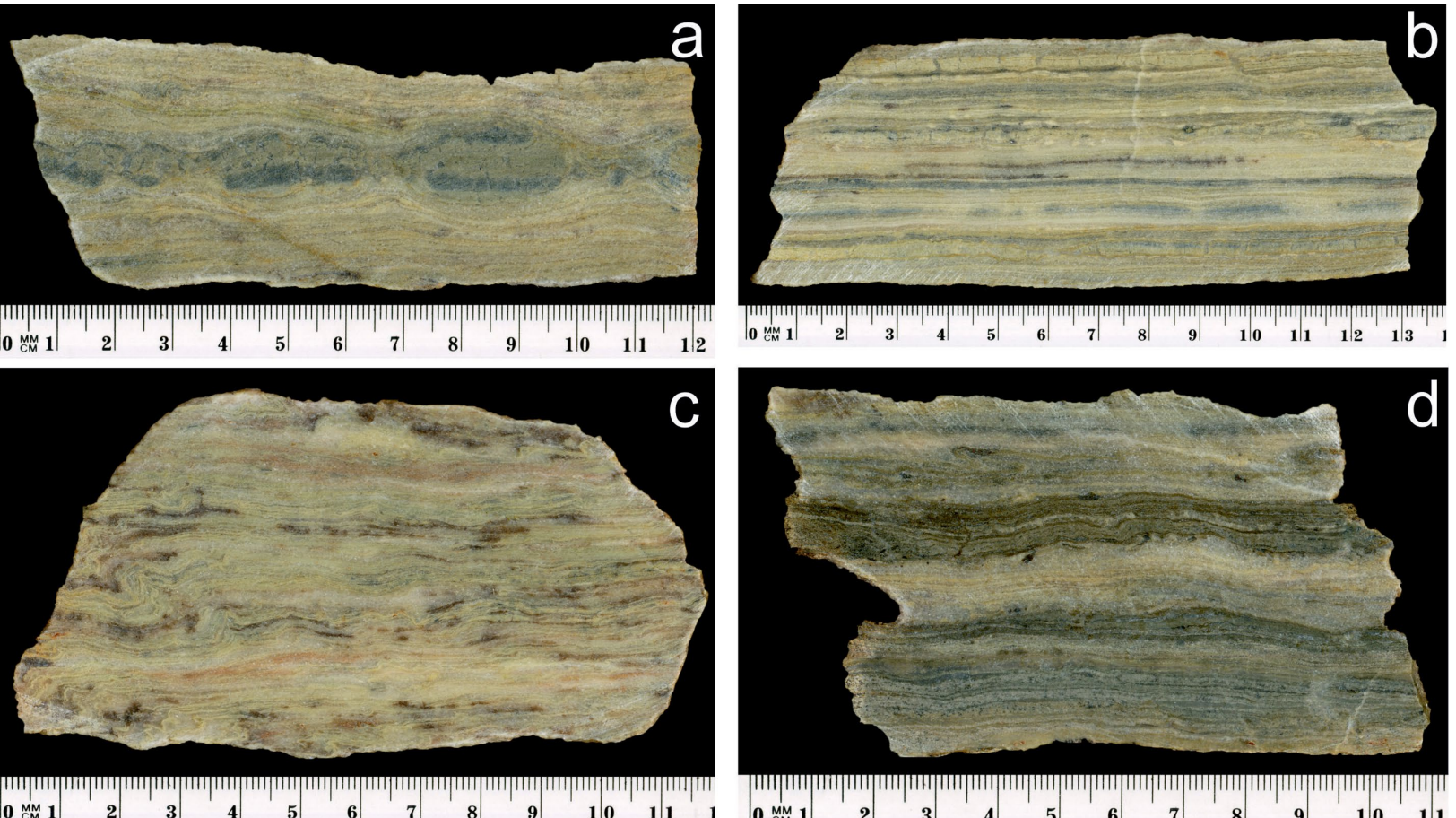

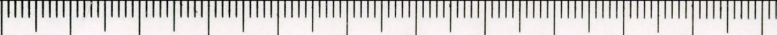

Obr. 4 Prierezy skúmaných vzoriek kryštalických vápencov: a) prejavy budinovania; b-d) horizontálne laminovaná textúra s miernymi znakmi zvrásnenia. Foto P. Ružička. tom regionálnej metamorfózy pôvodných lokálnych prejavov podmorského synsedimentárneho bázického vulkanizmu, ktorý bol považovaný za potenciálny zdroj mangánu (Kantor 1953, 1954; Fusán, Máška 1956; Ivanov 1960, 1965).

Metamanganolity sprevádzajú šošovky kryštalických vápencov, z časti ktorých sme robili detailný výskum minerálneho zloženia. Šošovky kryštalických vápencov sú uložené konformne s vrstevnatost'ou okolitých fylitov, pričom ich súčasná forma je výsledkom budinovania $v$ priebehu variskej metamorfózy a deformácie počas vývoja alpínskej vrásovo-prešmykovej stavby (Ilavský, Polák In: Slávik et al. 1967; Grecula et al. 1995; Rojkovič 1999, 2000, 2001; Lexa et al. 2007)

Na lokalite Čučma - Čierna baňa má genéza stratiformnej mangánovej mineralizácie polyštadiálny vývoj, čo dokazujú štúdie mnohých autorov (Maderspach 1880; Schafarzik 1904; Kantor 1953, 1954; Ilavský, Polák In: Slávik et al. 1967; Drnzík et al. 1973; Pecho et al. 1981; Grecula et al. 1995, 2011; Rojkovič 1999, 2000, 2001; Lexa et al. 2007). Primárny vulkanogénno-sedimentárny charakter mangánovej mineralizácie a sprievodných vápencov prepísalo pôsobenie variskej a alpínskej metamorfózy spolu s tektonickou aktivitou a neskoršími účinkami hydrotermálnych a hypergénnych proce- 
sov. Rojkovič $(1999,2000,2001)$ vyčlenil metamorfnú hydrotermálnu a hypergénnu asociáciu mangánovej mineralizácie. Jednotlivé minerály tvoriace danú minerálnu asociáciu potvrdili viacerí autori a niektorí z nich identifikovali aj d’alšie fázy (Faryad 1994; Faryad, Zábranský 1996; Peterec, Ďud'a 2003, 2009; Števko et al. 2015).

Podl'a Lázára (1959) sa t’ažba v oxidačnom pásme mangánovej mineralizácie začala od roku 1699. Názov Čierna baňa bol odvodený od t'ažby čiernych minerálov mangánu. Banskými prácami boli odkryté dve šošovky $s$ mangánovou mineralizáciou. Jedna $v$ banských poliach Ján a Laurent (banské miery udelené v roku 1878) a druhá v banskom poli Malvína (banská miera udelená $\mathrm{v}$ roku 1869). Údaje o minerálnom zložení, povrchové banské práce, pingy a štôlne opisujú Maderspach (1880), Tóth (1882), Schafarzik (1904), Eisele (1907) a Papp (1915).

Výskyt bol od polovice 19. storočia t’ažený povrchovým výlomom a dvoma krátkymi štôlňami. Geologickú pozíciu a genetické vzt'ahy metamanganolitov s kryštalickými vápencami znázornil Schafarzik (1904) v profile medzi hornou a dolnou štôlňou (obr. 3). Mangánová mineralizácia bola t’ažená len do híbky niekol'ko desiatok metrov (Ilavský, Polák In: Slávik et al. 1967; Pecho et al. 1981). V roku 1907 boli bane mimo prevádzky (Bergfest
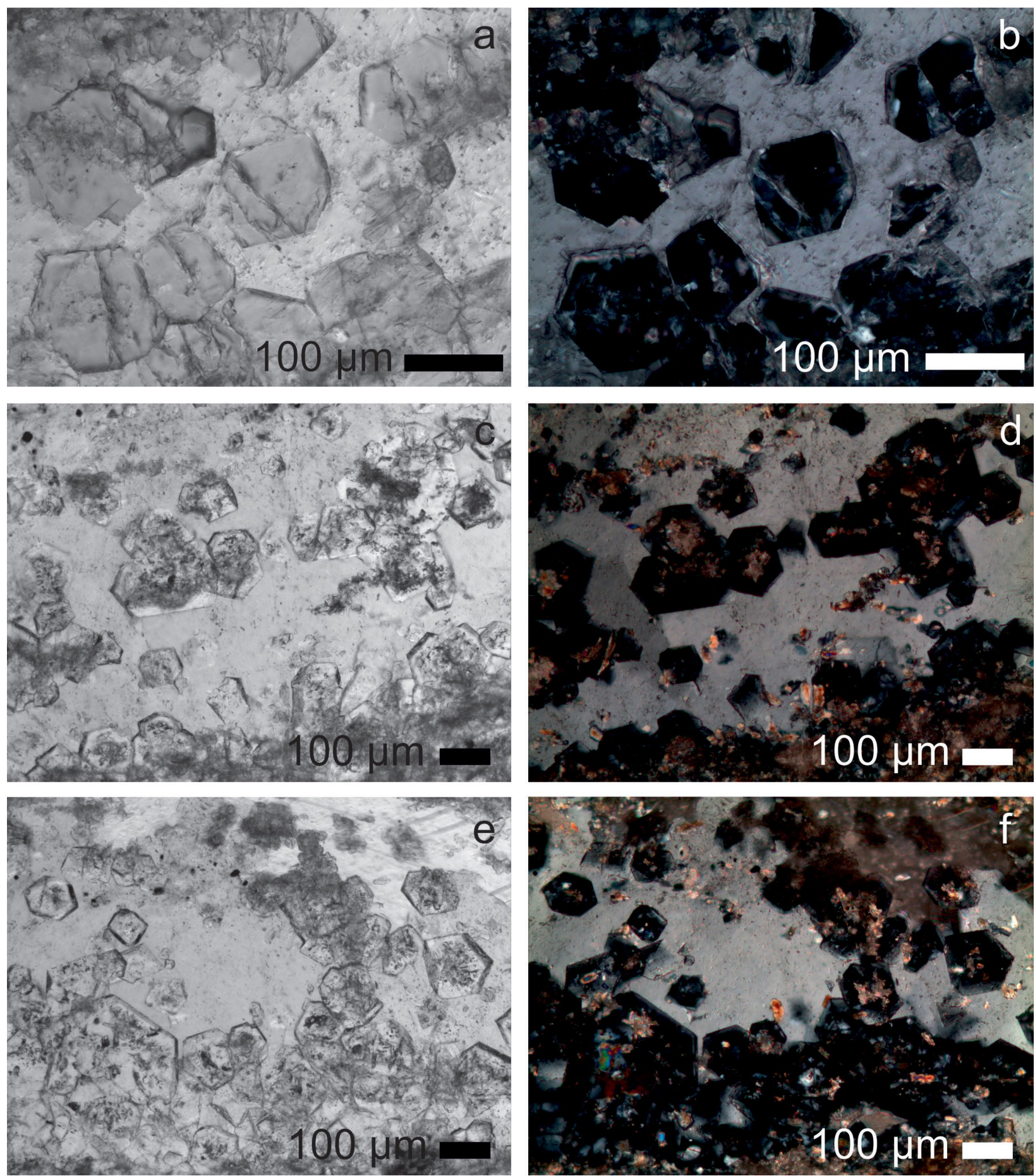

Obr. 5 Mikroskopické detaily polyedrických prierezov granátov v kryštalických vápencoch. Fotografie z polarizačného mikroskopu P. Ružička. 

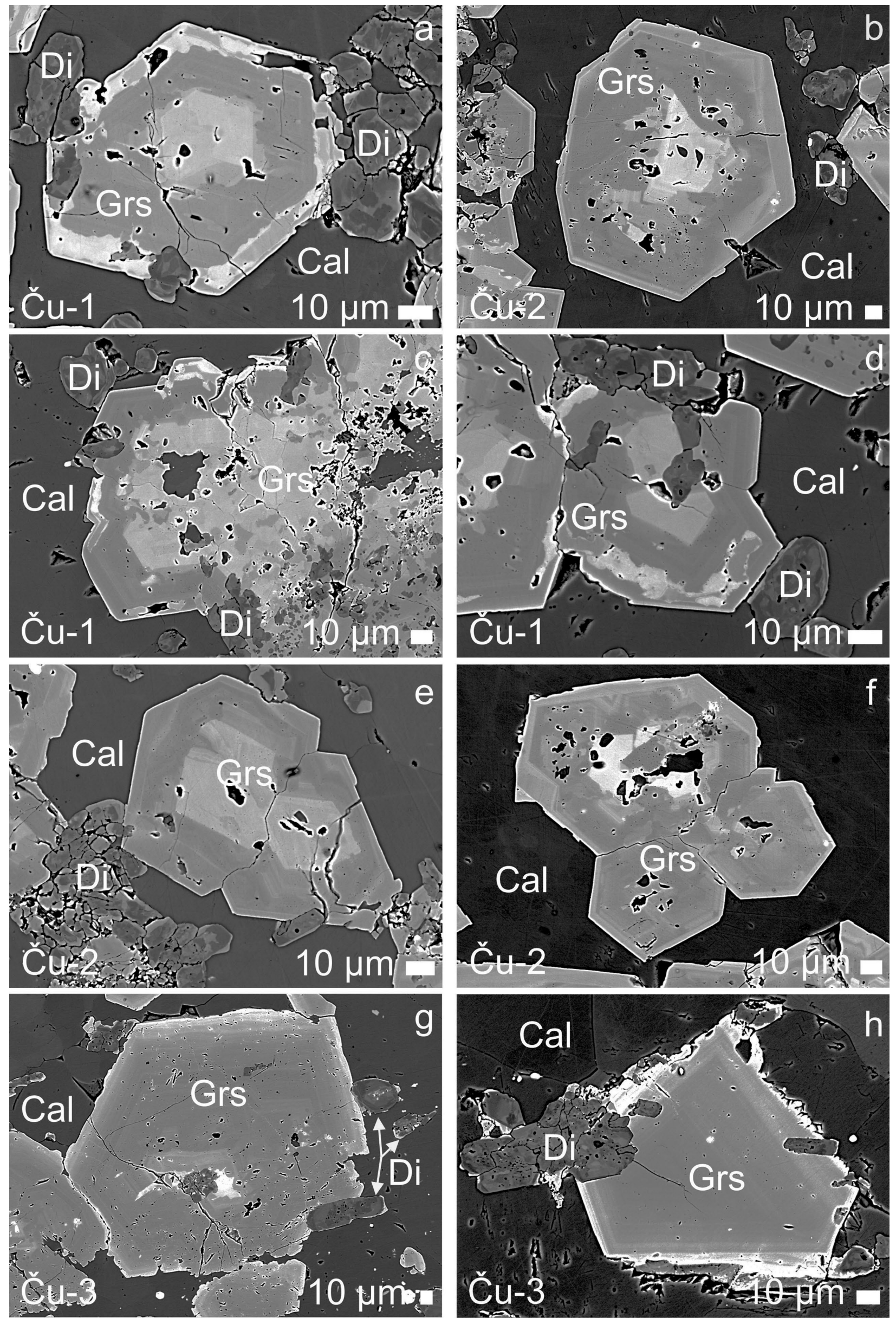

Obr. 6 Koexistenčné vzt’ahy zonálneho grosuláru (Grs) a diopsidu (Di) v kryštalickom vápenci kalcitového (Cal) zloženia. BSE foto S. Kurylo. 
1953). Hlavným predmetom t’ažby $v$ minulosti boli mangánové minerály supergénnej zóny (Maderspach 1880; Eisele 1907; Grecula et al. 1995, 2011; Ilavský, Polák In: Slávik et al. 1967; Rozložník 1973; Rojkovič 1999, 2000, 2001; Peterec, Ďud'a 2003, 2009; Lexa et al. 2007). Na jednotlivých haldách je dostupný materiál, ktorý umožňuje mineralogický výskum. Bane, ktoré sa v minulosti tažili, sú väčšinou neprístupné.

\section{Metodika}

Terénny odber bol zameraný na získanie reprezentačných vzoriek v rámci skúmanej lokality s ciel'om ich mikroskopického štúdia a následne mikrosondovej analýzy. Minerálne zloženie a mikroštruktúra kryštalických vápencov bola študovaná vo výbrusoch pomocou polarizačného mikroskopu Leica DM2500P na Katedre mineralógie a petrológie Prírodovedeckej fakulty Univerzity Komenského v Bratislave. Účelom mikroskopického pozorovania $v$ prechádzajúcom svetle bolo zistenie štruktúrnych vzt'ahov a vyznačenie fáz pre identifikáciu pomocou elektrónového mikroanalyzátora.

Leštené výbrusy, vákuovo naparené tenkou uhlíkovou vrstvou, boli analyzované na elektrónovom mikroanalyzátore JEOL JXA 8530FE na Ústave vied o Zemi Slovenskej akadémie vied $v$ Banskej Bystrici. Vzorky boli analyzované pri urýchl'ovacom napätí $15 \mathrm{kV}$ a prúde $20 \mathrm{nA}$ pre granáty a pyroxény a prúde 16 nA pre kalcit. Priemer elektrónového lúča sa prispôsoboval počas merania pre silikáty na $3-5 \mu \mathrm{m}$ a pre kalcit $8 \mu \mathrm{m}$. Použila sa ZAF korekcia. Koexistenčné vzt’ahy granátov a pyroxénov sa pozorovali v spätne rozptýlených elektrónoch (BSE - back scattered electron).

V granátoch sa analyzovali nasledovné prvky (kryštál, rtg. línie) za týchto štandardov: Si (TAP, Ka) - kremeň, Ti (LIF, Ka) - rutil, Al (TAP, Ka) - albit, Fe (LIF, Ka) - hematit, Mn (LIF, Ka) - rodonit, Mg (TAP, Ka) - diopsid, Ca (PETL, $\mathrm{Ka})$ - diopsid. Elektrónové mikroanalýzy granátov boli prepočítané v zmysle klasifikácie Grew et al. (2013) na 3 katióny $\mathrm{Ca}$, pretože všetky ostatné spôsoby prepočtu poskytli nestechiometrické vzorce. Kryštalografické pozície boli zapĺňané $v$ poradí $X \rightarrow Y \rightarrow Z$, aby sa dala odhalit' prípadná vakancia v pozícii $Z$. Pomer $\mathrm{Fe}^{2+} / \mathrm{Fe}^{3+}$ bol vypočítaný z nábojovej bilancie.

$\checkmark$ pyroxénoch sa analyzovali nasledovné prvky (kryštál, rtg. línie) za týchto štandardov: Si (TAP, Ka) - ortoklas, Ti (LIF, Ka) - rutil, Al (TAP, Ka) - albit, Fe (LIF, Ka) - biotit, Mn (LIF, Ka) - rodonit, Mg (TAP, Ka) - diopsid, Ca (PETL, Ka) - diopsid, Na (TAP, Ka) - albit. Elektrónové mikroanalýzy pyroxénov boli prepočítané $v$ zmysle klasifikácie Morimoto et al. (1988) na 4 katióny a pomer $\mathrm{Fe}^{2+} /$ $\mathrm{Fe}^{3+}$ bol vypočítaný $z$ nábojovej bilancie. $\mathrm{V}$ kalcitoch sa analyzovali nasledovné prvky (kryštál, rtg. línie) za týchto štandardov: Fe (LIFH, Ka) - hematit, Mn (LIFL, Ka) - rodonit, Mg (TAP, Ka) - diopsid, Ca (PETL, Ka) - diopsid.

$\checkmark$ texte používané slovenské názvy minerálov sú upravené podl'a Ozdína a Uhera (2002) a skratky minerálov sú uvádzané podla Siivola, Schmid In: Fettes, Desmons et al. (2007).

Tabul'ka 1 Reprezentatívne mikrosondové analýzy granátov (hm. \%) v kryštalických vápencoch prepočitané na 3 katióny Ca (apfu) a zastúpenie ich koncových členov (mol. \%).

\begin{tabular}{|c|c|c|c|c|c|c|c|c|c|c|c|}
\hline Analýza & 1 & 2 & 3 & 4 & 5 & 6 & 7 & 8 & 9 & 10 & 11 \\
\hline Vzorka & Ču-1 & Ču-1 & Ču-1 & Ču-1 & Ču-1 & Ču-2 & Ču-2 & Ču-2 & Ču-2 & Ču-3 & Ču-3 \\
\hline Zóna & $\begin{array}{l}\text { svetlý } \\
\text { stred }\end{array}$ & $\begin{array}{r}\text { tmavý } \\
\text { okraj }\end{array}$ & $\begin{array}{l}\text { svetlý } \\
\text { stred me }\end{array}$ & $\begin{array}{l}\text { tmavá } \\
\text { dzizóna }\end{array}$ & $\begin{array}{l}\text { svetlý } \\
\text { okraj }\end{array}$ & $\begin{array}{l}\text { svetlý } \\
\text { stred }\end{array}$ & $\begin{array}{r}\text { tmavý } \\
\text { okraj }\end{array}$ & $\begin{array}{l}\text { svetlý } \\
\text { stred }\end{array}$ & $\begin{array}{r}\text { tmavý } \\
\text { okraj }\end{array}$ & $\begin{array}{l}\text { tmavý } \\
\text { stred }\end{array}$ & $\begin{array}{r}\text { svetlý } \\
\text { okraj }\end{array}$ \\
\hline $\mathrm{SiO}_{2}$ & 37.30 & 39.21 & 36.99 & 38.29 & 37.94 & 38.22 & 38.79 & 37.99 & 38.95 & 38.70 & 37.73 \\
\hline $\mathrm{TiO}_{2}$ & 1.17 & 0 & 1.08 & 0.32 & 0.44 & 0.04 & 0.03 & 0.52 & 0.01 & 0.01 & 0.19 \\
\hline $\mathrm{Al}_{2} \mathrm{O}_{3}$ & 16.31 & 21.57 & 16.28 & 21.52 & 13.83 & 17.49 & 21.77 & 17.91 & 21.95 & 22.12 & 17.54 \\
\hline $\mathrm{Fe}_{2} \mathrm{O}_{3}$ & 8.29 & 1.52 & 8.24 & 1.61 & 11.79 & 7.49 & 1.59 & 6.22 & 1.05 & 1.43 & $7.1<$ \\
\hline $\mathrm{MnO}$ & 0.13 & 0.11 & 0.10 & 0.03 & 0.10 & 0.20 & 0.08 & 0.09 & 0.18 & 0 & 0.0 \\
\hline $\mathrm{MgO}$ & 0.03 & 0.01 & 0 & 0 & 0 & 0.02 & 0.02 & 0.04 & 0.02 & 0.02 & \\
\hline $\mathrm{CaO}$ & 36.59 & 37.33 & 36.79 & 37.60 & 36.31 & 37.02 & 37.38 & 37.04 & 37.70 & 37.72 & 36.61 \\
\hline Suma & 99.82 & 99.76 & 99.47 & 99.36 & 100.43 & 100.48 & 99.65 & 99.81 & 99.87 & 99.99 & 99.27 \\
\hline $\mathrm{Si}^{4+}$ & 2.854 & 2.941 & 2.815 & 2.851 & 2.926 & 2.891 & 2.906 & 2.871 & 2.893 & 2.873 & 2.88 \\
\hline $\mathrm{Al}^{3+}$ & 0.027 & 0.001 & 0 & 0 & 0 & 0.003 & 0.020 & 0 & 0 & 0.018 & 0.006 \\
\hline Suma & 2.882 & 2.941 & 2.815 & 2.851 & 2.926 & 2.894 & 2.926 & 2.871 & 2.893 & 2.891 & 2.89 \\
\hline$\overline{\mathrm{Ti}^{4+}}$ & 0.068 & 0 & 0.062 & 0.018 & 0.026 & 0.003 & 0.002 & 0.030 & 0 & 0 & 0.011 \\
\hline $\mathrm{Al}^{3+}$ & 1.443 & 1.906 & 1.460 & 1.889 & 1.257 & 1.557 & 1.901 & 1.595 & 1.921 & 1.918 & 1.575 \\
\hline $\mathrm{Fe}^{3+}$ & 0.478 & 0.086 & 0.472 & 0.090 & 0.684 & 0.426 & 0.090 & 0.354 & 0.059 & 0.080 & 0.411 \\
\hline $\mathrm{Mn}^{2+}$ & 0.009 & 0.007 & 0.007 & 0.002 & 0.007 & 0.013 & 0.005 & 0.006 & 0.012 & 0 & 0.003 \\
\hline $\mathrm{Mg}^{2+}$ & 0.003 & 0.001 & 0 & 0 & 0 & 0.002 & 0.002 & 0.005 & 0.002 & 0.002 & 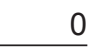 \\
\hline Suma & 2.000 & 2.000 & 2.000 & 1.999 & 1.974 & 2.000 & 2.000 & 1.989 & 1.994 & 2.000 & 2.000 \\
\hline $\mathrm{Ca}^{2+}$ & 3.000 & 3.000 & 3.000 & 3.000 & 3.000 & 3.000 & 3.000 & 3.000 & 3.000 & 3.000 & 3.000 \\
\hline Suma & 3.000 & 3.000 & 3.000 & 3.000 & 3.000 & 3.000 & 3.000 & 3.000 & 3.000 & 3.000 & 3.000 \\
\hline Pyrop & 0 & 0 & 0 & 0 & 0 & 0 & 0 & 0 & 0 & 0 & \\
\hline Spessartin & 0 & 0 & 0 & 0 & 0 & 0 & 0 & 0 & 0 & 0 & \\
\hline Almandín & 0 & 0 & 0 & 0 & 0 & 0 & 0 & 0 & 0 & 0 & \\
\hline Andradit & 23.88 & 4.29 & 23.59 & 4.52 & 34.22 & 21.32 & 4.49 & 17.69 & 2.95 & 3.99 & 20.55 \\
\hline Grosulár & 76.12 & 95.71 & 76.41 & 95.48 & 65.78 & 78.68 & 95.51 & 82.31 & 97.05 & 96.01 & 79.45 \\
\hline
\end{tabular}




\section{Výsledky}

Kryštalické vápence sú sivožlté až hnedozelené horniny s prevažne jemnokryštalickou až masívnou alebo horizontálne laminovanou textúrou (obr. 4) a granoblastickou štruktúrou. Kryštalické vápence majú kalcitové zloženie (tab. 3). Prítomnost' dolomitu sa nepotvrdila.

Granáty v kryštalických vápencoch tvoria nepravidelné hniezda a polohy prebiehajúce paralelne s pôvodnou vrstevnatost'ou. Idiomorfné zrná granátov, ktoré si zachovávajú pravidelné polyedrické ohraničenie sa zoskupujú do agregátov (obr. 5). Granáty a diopsid prejavujú zonálnost' a často vzájomne koexistujú (obr. 6).

Študované granáty majú zloženie grosuláru s variabilným podielom andraditovej molekuly (tab. 1, obr. 7b). Všetky ostatné komponenty sú zanedbatel'né pri vel'mi nízkych obsahoch $\mathrm{Mg}$ (do $0.005 \mathrm{apfu}$ ) a $\mathrm{Mn}$ (do 0.013 apfu). Granáty vo vzorkách Ču-1 a Ču-2 majú stred s vyšším podielom andraditovej molekuly (17.69 - $23.88 \mathrm{~mol}$.
\%) a okraj s jej nízkym obsahom (2.95 - 4.52 mol. \%), len jeden kryštál má na okraji ešte jednu zónu výrazne obohatenú o andraditový komponent (34.22 mol. \%). Vzorka Ču-3 má inverznú zonálnost' s výrazne grosulárovým stredom (96.01 mol. \%), ale naopak okraj je obohatený o andraditový komponent (20.55 mol. \%). Všetky analýzy pri prepočte na 3 Ca katióny majú mierne znížený obsah katiónov v pozícii Z, čo môže signalizovat' prítomnost' vakancie a $\mathrm{OH}$ skupín a teda hydrogranátového komponentu. Vzhl'adom na sumy analýz granátov predpokladáme, že pravdepodobná prítomnost' $\mathrm{OH}$ skupín by sa v Ramanovom spektre nemusela výraznejšie prejavit'. $Z$ tohto dôvodu Ramanove spektrá neuvádzame, ale $v$ budúcnosti nevylučujeme možnost' zamerat' sa na objasnenie prítomnosti hydrogranátového komponentu.

Analyzované pyroxény majú zloženie diopsidu s variabilným pomerom $\mathrm{Mg} /\left(\mathrm{Mg}+\mathrm{Fe}^{2+}\right.$ ) (tab. 2, obr. 7a). Zvýšený obsah $\mathrm{Fe}^{3+}$ vypočítaného $z$ nábojovej bilancie je mož-

Tabul'ka 2 Reprezentatívne mikrosondové analýzy diopsidu v kryštalických vápencoch (hm. \%). Prepočet na 4 katióny (apfu) a zastúpenie ich koncových členov (mol. \%).

\begin{tabular}{|c|c|c|c|c|c|c|c|c|c|c|c|c|}
\hline Analýza & 1 & 2 & 3 & 4 & 5 & 6 & 7 & 8 & 9 & 10 & 11 & 12 \\
\hline Vzorka & Ču-1 & Ču-1 & Ču-1 & Ču-1 & Ču-2 & Ču-2 & Ču-2 & Ču-2 & Ču-2 & Ču-2 & Ču-3 & Ču-3 \\
\hline Zóna & svetlá & tmavá & svetlá & tmavá & svetlá & tmavá & svetlá & tmavá & svetlá & tmavá & svetlá & tmavá \\
\hline $\mathrm{SiO}_{2}$ & 53.83 & 54.92 & 53.60 & 54.30 & 54.23 & 55.03 & 52.97 & 54.97 & 52.68 & 53.59 & 53.67 & 54.64 \\
\hline $\mathrm{iO}_{2}$ & 0 & 0 & 0.01 & 0 & 0 & 0.03 & 0.01 & 0 & 0 & 0.03 & 0 & \\
\hline $\mathrm{I}_{2} \mathrm{O}_{3}$ & 0.32 & 0.10 & 0.53 & 0.02 & 0.34 & 0.07 & 0.28 & 0.29 & 0.14 & 0.54 & 1.17 & 0.59 \\
\hline $\mathrm{Fe}_{2} \mathrm{O}_{3}$ & 1.52 & 0.58 & 2.23 & 0.83 & 0.62 & 0.84 & 0.25 & 0.23 & 0.84 & 0 & 0.71 & 1.03 \\
\hline $\mathrm{eO}$ & 4.15 & 0 & 3.36 & 0 & 4.53 & 0.99 & 6.85 & 1.91 & 10.53 & 3.01 & 2.41 & 0.80 \\
\hline $\mathrm{nO}$ & 0.35 & 0.19 & 0.20 & 0.28 & 0.22 & 0.30 & 2.93 & 0.42 & 0.80 & 3.19 & 0.32 & 0.17 \\
\hline $\mathrm{gO}$ & 15.12 & 19.00 & 15.53 & 18.49 & 15.02 & 17.46 & 11.67 & 16.83 & 10.72 & 13.12 & 15.81 & 17.22 \\
\hline $\mathrm{CaO}$ & 25.48 & 26.14 & 25.13 & 26.27 & 25.53 & 25.96 & 24.58 & 25.94 & 25.11 & 25.44 & 25.53 & 25.93 \\
\hline $\mathrm{Na}_{2} \mathrm{O}$ & 0.06 & 0.02 & 0.14 & 0.01 & 0.13 & 0.04 & 0.27 & 0.03 & 0.08 & 0.18 & 0.12 & 0.10 \\
\hline Suma & 0.67 & 100.90 & 0.51 & 100.11 & 100.56 & 100.63 & 99.79 & 100.59 & 100.81 & 99.10 & 99.66 & 100.36 \\
\hline$\widehat{\mathrm{Si}^{4+}}$ & 1.974 & 1.961 & 1.963 & 1.958 & 1.989 & 1.988 & 2.000 & 1.992 & 1.988 & 2.010 & 1.969 & 1.977 \\
\hline $\mathrm{Al}^{3+}$ & 0.014 & 0.004 & 0.023 & 0.001 & 0.011 & 0.003 & 0 & 0.008 & 0.006 & 0 & 0.031 & 0.023 \\
\hline Suma & 1.988 & 1.966 & 1.985 & 1.959 & 2.000 & 1.990 & 2.000 & 2.000 & 1.994 & 2.010 & 2.000 & 2.000 \\
\hline$\overline{\mathrm{Ti} i^{4+}}$ & 0 & 0 & 0 & 0 & 0 & 0.001 & 0 & 0 & 0 & 0.001 & 0 & \\
\hline $\mathrm{Al}^{3+}$ & 0 & 0 & 0 & 0 & 0.003 & 0 & 0.012 & 0.004 & 0 & 0.024 & 0.020 & 0.002 \\
\hline$e^{3+}$ & 0.042 & 0.016 & 0.062 & 0.023 & 0.017 & 0.023 & 0.007 & 0.006 & 0.024 & 0 & 0.020 & 0.028 \\
\hline $\mathrm{Mg}^{2+}$ & 0.827 & 0.984 & 0.848 & 0.977 & 0.821 & 0.940 & 0.657 & 0.909 & 0.603 & 0.734 & 0.865 & 0.929 \\
\hline$e^{2+}$ & 0.127 & 0 & 0.090 & 0 & 0.139 & 0.030 & 0.216 & 0.058 & 0.332 & 0.095 & 0.074 & 0.024 \\
\hline $\mathrm{Mn}^{2+}$ & 0.004 & 0 & 0 & 0 & 0.007 & 0.007 & 0.094 & 0.013 & 0.025 & 0.101 & 0.010 & 0.005 \\
\hline Suma & 1.000 & 1.000 & 1.000 & 1.000 & 0.988 & 1.000 & 0.986 & 0.991 & 0.985 & 0.954 & 0.988 & 0.988 \\
\hline $\mathrm{Fe}^{2+}$ & 0 & 0 & 0.013 & 0 & 0 & 0 & 0 & 0 & 0 & 0 & 0 & \\
\hline $\mathrm{Mn}^{2+}$ & 0.007 & 0.006 & 0.006 & 0.008 & 0 & 0.003 & 0 & 0 & 0 & 0 & 0 & \\
\hline $2+$ & 0 & 0.027 & 0 & 0.017 & 0 & 0 & 0 & 0 & 0 & 0 & 0 & \\
\hline & 01 & 1.000 & 86 & 1.015 & 03 & 1.005 & 0.994 & 07 & 1.015 & 1.022 & 1.004 & 1.005 \\
\hline $\mathrm{Na}^{+}$ & 0.004 & 0.001 & 0.010 & 0.001 & 0.009 & 0.002 & 0.019 & 0.002 & 0.006 & 0.013 & 0.009 & 0.007 \\
\hline Suma & 1.012 & 1.034 & 1.015 & 1.041 & 1.012 & 1.010 & 1.014 & 1.009 & 1.021 & 1.035 & 1.012 & 1.012 \\
\hline Wo & 50.07 & 49.44 & 49.23 & 50.47 & 49.69 & 50.30 & 47.22 & 49.83 & 50.12 & 49.11 & 49.16 & 49.55 \\
\hline En & 42.11 & 50.23 & 43.32 & 49.44 & 41.44 & 47.47 & 34.45 & 45.95 & 30.73 & 39.08 & 44.13 & 47.10 \\
\hline Fs & 6.48 & 0 & 5.25 & 0 & 7.01 & 1.51 & 11.35 & 2.92 & 16.93 & 5.03 & 3.77 & 1.22 \\
\hline Jh & 0.21 & 0 & 0 & 0 & 0.35 & 0.34 & 4.92 & 0.65 & 1.29 & 5.39 & 0.50 & 0.27 \\
\hline $\mathrm{Ae}$ & 0.31 & 0.09 & 0.75 & 0.06 & 0.51 & 0.22 & 0.73 & 0.08 & 0.47 & 0 & 0.24 & 0.36 \\
\hline Jd & 0.10 & 0.02 & 0.28 & 0 & 0.43 & 0.03 & 1.30 & 0.16 & 0.13 & 1.39 & 0.63 & 0.32 \\
\hline Ca-Ts & 0.71 & 0.21 & 1.13 & 0.03 & 0.57 & 0.06 & 0 & 0.41 & 0.32 & 0 & 1.57 & 1.17 \\
\hline Ti-Ts & 0 & 0 & 0.02 & 0 & 0 & 0.04 & 0.02 & 0 & 0 & 0.05 & 0 & \\
\hline Mg-Ts & 0 & 0 & 0.02 & 0 & 0 & 0.04 & 0.02 & 0 & 0 & 0.05 & 0 & \\
\hline
\end{tabular}



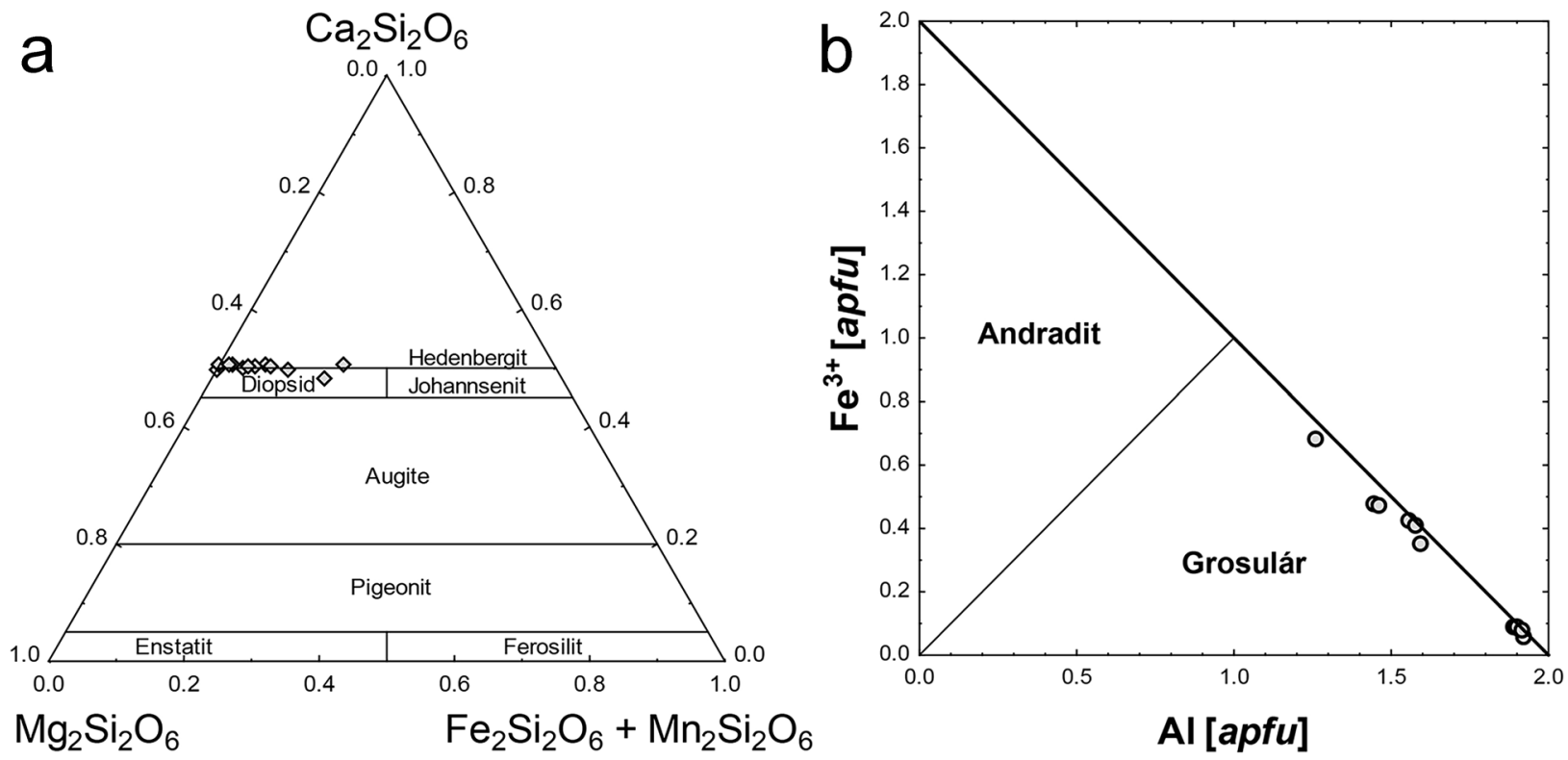

Obr. 7 Zobrazenie analyzovaných silikátov v klasifikačných diagramoch: a) pyroxény (Morimoto et al. 1988); b) granáty (Grew et al. 2013).

né vysvetlit' prítomnost'ou egirínovej molekuly (do 0.73 mol. \%) prostredníctvom substitúcie $\mathrm{NaFe}^{3+}(\mathrm{CaMg})_{-1}$, ale pri nízkych obsahoch $\mathrm{Na}$ a $\mathrm{Al}$ môže byt' čast' $\mathrm{Fe}^{3+}$ zapojená do niektorej z tschermakitových substitúcií, t. j. do Ca-tschermakitovej $\left(\mathrm{CaFe}^{3+} \mathrm{SiAlO}_{6}\right)$ alebo Mg-tschermakitovej $\left(\mathrm{MgFe}^{3+} \mathrm{SiAlO}_{6}\right)$ ako ${ }^{\mathrm{V}} \mathrm{Fe}^{3+\mathrm{IV}} \mathrm{Al}\left({ }^{\mathrm{VI}} \mathrm{Mg}^{\mathrm{IV} S i}\right)_{-1}$, možná je aj Ti-tschermakitová $\left(\mathrm{CaTi}_{0.5} \mathrm{Mg}_{0.5} \mathrm{SiFe}^{3+} \mathrm{O}_{6}\right)$ substitúcia vo forme ${ }^{\mathrm{V}} \mathrm{Ti}^{\mathrm{IV}} \mathrm{Fe}^{3+}\left({ }^{\mathrm{V}} \mathrm{Mg}^{\mathrm{IV}} \mathrm{Si}\right)_{-1}$. Mierne zvýšený je aj obsah $\mathrm{Mn}$ (do 0.09 apfu), ktorý vystupuje $v$ rámci johannsenitovej molekuly.

\section{Diskusia}

Kryštalické vápence na lokalite Čučma - Čierna baňa sú súčast'ou metamanganolitov, ktorých mineralizácie boli $v$ minulosti skúmané hlavne $z$ genetických aspektov (napr. Kantor 1953, 1954; Ilavský 1957, 1962, 1974; Varček 1963; Ilavský, Polák In: Slávik et al. 1967; Faryad 1994; Grecula et al. 1995, 2011; Rojkovič 1999, 2000, 2001; Peterec, Ďud'a 2003, 2009). Z geologického hl'adiska kryštalické vápence tvoria súčast' litostratigraficky ekvivalentných metakarbonátových pruhov gelnickej skupiny južného gemerika s úzkou a prerušovanou kontinuitou povrchových výskytov (Fusán et al. 1955; Fusán, Máška 1956; Fusán 1957; Gregor et al. 1964; Snopko 1967; llavský 1974; Bajaník et al. 1983, 1984; Vážna et al. 1986).

Z mangánového výskytu Čučma - Čierna baňa sa uvádza len granát $s$ dominantným podielom spessartínového zloženia, ktorý je súčast'ou minerálnej asociácie metamanganolitov (Kantor 1953, 1954; Faryad 1994; Grecula et al. 1995, 2011; Rojkovič 1999, 2000, 2001; Peterec, Ďud’a 2003, 2009). Spessartínový granát spomínajú Kantor $(1953,1954)$ a Ivanov $(1960,1965)$ aj v kryštalických vápencoch a bazaltových metavulkanoklastikách.

Prítomnost' granátov považovali za produkt látkovej migrácie roztokov pri metamorfných procesoch, ktoré sa odohrali na styku produktov bázického vulkanizmu s karbonátmi. Naše zistenia ale rozporujú informácie uvedené v starších prácach Kantora $(1953,1954)$ a Ivanova (1960, 1965) o charaktere granátov v kryštalických vápencoch z Čučmy. Odobraté vzorky kryštalických vápencov priamo z haldového materiálu po t’ažbe mangánových rúd,
Tabul'ka 3 Reprezentatívne mikrosondové analýzy kalcitu (hm. \%) prepočítané na 1 atóm kyslíka. Symbol * vyjadruje dopočítanie $\mathrm{CO}_{2}$.

\begin{tabular}{lrrrrrr}
\hline Analýza & 1 & 2 & 3 & 4 & 5 & 6 \\
\hline $\mathrm{FeO}$ & 0.07 & 0.05 & 0.03 & 0.01 & 0.03 & 0.02 \\
$\mathrm{MnO}$ & 0.10 & 0.27 & 0.11 & 0.08 & 0.06 & 0.11 \\
$\mathrm{MgO}$ & 0.01 & 0 & 0 & 0 & 0 & 0.02 \\
$\mathrm{CaO}$ & 55.63 & 56.06 & 56.12 & 56.21 & 56.37 & 56.43 \\
$\mathrm{CO}_{2}{ }^{*}$ & 43.81 & 44.20 & 44.12 & 44.21 & 44.32 & 44.40 \\
\hline $\mathrm{Suma}^{2}$ & 99.62 & 100.58 & 100.38 & 100.51 & 100.78 & 100.98 \\
\hline $\mathrm{Fe}^{2+}$ & 0.001 & 0.001 & 0 & 0 & 0 & 0 \\
$\mathrm{Mn}^{2+}$ & 0.001 & 0.004 & 0.002 & 0.001 & 0.001 & 0.002 \\
$\mathrm{Mg}^{2+}$ & 0 & 0 & 0 & 0 & 0 & 0 \\
$\mathrm{Ca}^{2+}$ & 0.997 & 0.995 & 0.998 & 0.999 & 0.999 & 0.998 \\
\hline $\mathrm{Suma}^{2+}$ & 1.000 & 1.000 & 1.000 & 1.000 & 1.000 & 1.000 \\
\hline & & & & & &
\end{tabular}

ktoré sme študovali, jasne preukázali prítomnost' zonálnych granátov prevažne grosulárového zloženia. Grosulárová a andraditová zložka sa variabilne strieda vo vzorkách Ču-1 a Ču-2 medzi stredom (Grs ${ }_{76.12-82.31} ; \operatorname{Adr}_{17.69-23.88}$ ) a okrajom $\left(\mathrm{Grs}_{95.48-97.05} ; \mathrm{Adr}_{2.95-4.52}\right)$. V prípade vzorky Cu-3 je prítomná inverzná zonálnost' (stred $\mathrm{Adr}_{3.99}, \mathrm{Grs}_{96.01}$; okraj $\left.\mathrm{Adr}_{20.55}, \mathrm{Grs}_{79.45}\right)$. Grosulárovo-andraditové granáty spolu $\mathrm{s}$ diopsidom sa tvoria počas regionálnej a kontaktnej metamorfózy karbonátov. Príkladom sú granáty obsahujúce $\mathrm{Grs}_{70-84}$ a Adr ${ }_{14-29}$ (Vassileva et al. 2018) resp. Grs (V8.24-91.41 a $\operatorname{Adr}_{6.50-21.60}$ (Ahmed, Hariri 2006), ktoré sú čiastočne porovnatel'né s našimi analyzovanými granátmi.

$\checkmark$ rámci staršieho paleozoika gemerika $v$ horninách rakoveckej skupiny, vo vrte RHV-1 južne od Rudnian, bola zistená poloha spessartínovo-piemontitových metakonkrécií (Spišiak et al. 1989). Táto práca potvrdila predpoklad, že zvýšený obsah mangánu $v$ pôvodných pelagických sedimentoch bol podmienený prítomnost'ou produktov bázického vulkanizmu, prípadne exhalačnou a hydrotermálnou činnost'ou viazanou na vulkanizmus, čo je v zhode $s$ doposial' známymi údajmi z Čučmy. Pelagické sedimenty boli metamorfované $v$ podmienkach fácie zelených bridlíc. Identifikovaný granát mal zloženie 
$\mathrm{Sps}_{80-87} \mathrm{Grs}_{7-11.5} \mathrm{Alm}_{3-8.3}$ a Mn-epidot viazaný na lem metakonkrécií obsahoval $2 \%$ piemontitovej zložky (Spišiak et al. 1989).

Štúdiu Radvanec et al. (2007) uvádzame v kontexte korelácie zonálnych granátov pochádzajúcich z metapelitu tvoriaceho súčast' horninovej sekvencie gelnickej skupiny južného gemerika. Radvanec et al. (2007) identifikovali zonálny granát $z$ vrtu RS-1/520 m vo vzorke RS15 (Bt-metapelit) z lokality Gulapalag, ktorá je situovaná v širšom okolí Čučmy. Granát mal v strede dominantnú spessartínovú zložku ( $\left.\operatorname{Sps}_{57-66} \mathrm{Alm}_{21-23} \mathrm{Grs}_{11-19}\right)$ a na okraji grosulárovú zložku $\left(\mathrm{Grs}_{42-54} \mathrm{Alm}_{21-33} \mathrm{Sps}_{21-26}\right)$. Pri porovnaní $\mathrm{s}$ našimi výsledkami opät' platí len čiastočná zhoda v tom, že sme identifikovali grosulárovú zložku v zonálnom granáte. Radvancom et al. (2007; 2009) bližšie nešpecifikovaný horninový typ označený ako Bt-metapelit má datovaný permský vek. $V$ permskom období počas formovania gemerických granitov prebiehali procesy poskytujúce dostatok tepla pre vyššie teplotnú metamorfózu, transport fluíd, ktoré mali vplyv aj na dotvorenie genézy mangánovej mineralizácie čučmianskeho typu. Faryad (1991) vyslovil názor, že genéza metamanganolitov bola ovplyvnená termálnou reaktiváciou $v$ dôsledku intrúzie granitov gemerika, pričom vylučuje prejavy kontaktnej metamorfózy granitov.

\section{Záver}

$\mathrm{V}$ rámci systematického mineralogického výskumu kryštalických vápencov sme na lokalite Čučma - Čierna baňa prvý krát identifikovali prítomnost' zonálneho granátu prevažne grosulárového zloženia a diopsid. V starších informačných zdrojoch sa zo skúmanej lokality uvádzal len spessartínový granát a diopsid nikto pred nami neidentifikoval. Príspevok poskytuje nové údaje, ktoré rozširujú mineralogické poznatky o tejto historicky známej mangánovej lokalite Slovenska. Prezentované výsledky potvrdili potrebu detailného mineralogického štúdia sprievodných hornín metamanganolitov, pretože štúdie v minulosti boli zamerané len priamo na identifikáciu minerálnych asociácií metamanganolitov a ich genézu. Dešifrovanie interakcií sprievodných hornín s metamanganolitmi bude súčast'ou budúceho výskumu.

\section{Pod'akovanie}

Vyslovujeme pod'akovanie recenzentom článku za podnetné pripomienky, ktoré prispeli k skvalitneniu rukopisu. Táto práca bola podporovaná Agentúrou na podporu výskumu a vývoja na základe zmluvy č. APVV-15-0050 a grantom VEGA 1/0151/19.

\section{Literatúra}

AHMED Z, HARIRI M M (2006) Formation and mineral chemistry of a calcite skarn from Al-Madhiq, SW Saudi Arabia. Chem Erde 66:187-201

Bajaní Š, Vozárová A (ed.), Hanzel V, IVanička J, Mello J, Pristaš J, Reichwalder P, Snopko L, VozÁr J (1983) Vysvetlivky ku geologickej mape Slovenského rudohoria - východná čast' 1: 50 000. ŠGÚDŠ, Bratislava, 1-223

Bajaní Š (ed.), IVANičKa J, Mello J, Pristaš J, Reichwalder P, Snopko L, Vozár J, Vozárová A (1984) Geologická mapa Slovenského rudohoria - východná čast' 1: 50 000. ŠGÚDŠ, Bratislava

Bergfest A (1953) Čučma (Sb). Spišská Baňa (Sb). Baníctvo v okolí Čučmy. MS, Geofond - archív ŠGÚDŠ, Bratislava, $65 \mathrm{~s}$
Drnzík E (ed.), Drnzíková L, Grecula P, Gregor T, HalaHYOVÁ-ANDRUSOVOVÁ G, ILAVSKÝ J, ONDREJKoVIČ K, ZORKovskÝ B (1973) Geologicko-ložisková štúdia Spišsko-gemerského rudohoria. 3. Ložisková čast'. Kniha VI. MS, Geofond - archív ŠGÚDŠ, Bratislava, $280 \mathrm{~s}$

EISELE G (1907) Gömör és Borsod vármegyék bányászati és kohászati monografiája. Első rész. Gömör és Kishont törvényesen egyesült vármegyének bányászati monografiája. Selmeczbánya, $546 \mathrm{~s}$

FARYAD S W (1991) Metamorfóza sedimentov staršieho paleozoika gemerika. Miner Slov 23, 4: 315-324

FARYAD S W (1994) Mineralogy of Mn-rich rocks from greenschist facies sequences of the Gemericum, West Carpathians, Slovakia. N Jb Miner Mh H 10: 464-480

FARYAD S W (1995) Stanovenie P-T podmienok metamorfózy horninových komplexov Spišsko-gemerského rudohoria. Miner Slov 27, 1: 9-19

FARYAD S W (1997) Metamorphic petrology of the Early Paleozoic low-grade rocks in the Gemericum. In: Grecula P, Hovorka D, Putiš M. (eds.): Geological evolution of the Western Carpathians. Miner Slov monograph 309-314

FARYAD S W, ZÁBRANSKÝ F (1996) Novozistené horninotvorné minerály metamorfitov $Z$ východnej časti Slovenského rudohoria. Acta Montan Slov 1, 2: 131-138

FusÁn O (1957) Paleozoikum gemeríd. Geol Práce Zoš 46: $17-37$

FusÁN O, MÁšKA M (1956) K stratigrafii gotlandu (?) v gemeridách. Geol Práce Zpr 7: 65-74

Fusán O, MÁšKa M, ZouBEK V (1955) Niektoré dnešné problémy stratigrafie Spišsko-gemerského paleozoika. Geol Práce Zpr 2: 3-15

GRECULA P (1982) Gemerikum - segment riftogénneho bazénu Paleotetýdy. Miner Slov monograph, $263 \mathrm{~s}$

Grecula P, Radvanec M (2005) Geotektonický model vývoja gemerika. Miner Slov 37, 3: 193-198

Grecula P, Abonyı A, Abonyıová M, Antaš J, Bartalský B, BaRTALSKÝ J, DianIŠKA I, DrnziK E, Ďuďa R, GaRgulák M, GAZDAČKo L', HUdÁČEK J, KobULSKÝ J, LÖRINCZ L, MACKO J, NÁvesñák D, Németh Z, Novotný L, Radvanec M, RoJKOVIČ I, ROZLoŽNíK L, ROZLOŽNiK O, VARČEK C, ZLOCHA J (1995) Ložiská nerastných surovín Slovenského rudohoria. Zväzok 1. Miner Slov monograph, $834 \mathrm{~s}$

Grecula P (ed.), Kobulský J, Gazdačko L', Németh Z, Hraško L', Novotný L, MAgLAY J (2009) Geologická mapa Spišsko-gemerského rudohoria 1: 50 000. ŠGúDŠ, Bratislava.

Grecula P, Kobulský J (eds.), Gazdačko L', Németh Z, Hraško L', Novotný L, Maglay J, Pramuka S, Radvanec M, KuCHARIČ L', BaJtoš P, ZÁHOROVÁ L' (2011) Vysvetlivky ku geologickej mape Spišsko-gemerského rudohoria 1: 50 000. ŠGÚDŠ, Bratislava, $308 \mathrm{~s}$

Gregor T, ILAVSKÝ J, Kantor J (1964) Štúdium vápencov silúru gemeríd s ciel'om vypracovania stratigraficko-štruktúrnych kritérií pre vyhl'adávanie rúd (hlavne metasomatických sideritov). Zpr o geol výsk v roku 1963, 2 - Slovensko, 42-45

Grew E S, Locock A J, Mills S J, Galuskina I O, Galuskin E V, HÅlenius U (2013) Nomenclature of the garnet supergroup. Am Mineral 98: 785-811

ILAVSkÝ J (1957) Geológia rudných ložísk Spišsko-gemerského rudohoria. Geol Práce Zoš 46: 51-95

ILAVSKÝ J (1962) Metalogenetický vývoj gemeríd a jeho problémy. Geol Práce Zoš 61: 87-100 
ILAVSKÝ J (1974) Príspevok k paleogeografii gelnickej série gemeríd na základe rozšírenia stratiformných zrudnení. Západ Karpaty sér miner petrogr geochem ložiská 1: $51-97$

ILAVSKÝ J, POLÁK S (1967) Mangánové rudy. In: Slávik J (eds.) et al.: Nerastné suroviny Slovenska. SVTL, Bratislava, 118-127

IVANIČKA J, SnOPKo L, Snopková P, VozáRovÁ A (1989) Gelnica Group - lower unit of Spišsko-gemerské rudohorie Mts. (West Carpathians) Early Palaeozoic. Geol Zbor Geol Carpath 40, 4: 483-501

IvANov M (1960) Bázický vulkanizmus gelnickej série v gemeridách. Geol Práce Zpr 19: 157-161

IvANOv M (1965) Litológia, petrografia a metamorfizmus paleozoika Spišsko-gemerského rudohoria. Sbor Geol vied ZK 3: 43-92

KANTOR J (1953) Mangánové ložisko pri Čučme. MS, Geofond - archív ŠGÚDŠ, Bratislava, $32 \mathrm{~s}$

KANTOR J (1954) O genéze mangánových rúd v Spišskogemerskom rudohorí. Geol Práce Zpr 1: 70-71

LÁZÁR V (1959) Správa o archívno-výskumnej úlohe „Ankeritový pruh Hanková - Volovec" v roku 1959. MS, Geofond - archív ŠGÚDŠ, Bratislava, $82 \mathrm{~s}$

Lexa J (ed.), Bačo P, Hurai V, Chovan M, Koděra P, Petro M, RoJkovič I, TRÉGER M (2007) Vysvetlivky k metalogenetickej mape Slovenskej republiky 1: 500000. ŠGÚDŠ, Bratislava, $178 \mathrm{~s}$

MADERSPACH L (1880) Magyarország vasércz-fekhelyei. Kiadja a Kir. Magyar Természettudományi Társulat, Budapest, $111 \mathrm{~s}$

MazúR E, LukNiš M (1980) Geomorfologické jednotky (mapa 1: 500 000). In: Mazúr E, Jakál J (eds.): Atlas SSR. SAV a Slov úrad geod a kart Bratislava, 54-55

MAZZOLI C, VozÁRovÁA (1989) Further data concerning the pressure character of the Hercynian metamorphism in the West Carpathians (Czechoslovakia). Rend Soc Ital Min Petr 43, 3: 635-642

Morimoto N, Fabries J, Ferguson AK, Ginzburg IV, Ross M, Seifert FA, Zussman J (1988) Nomenclature of pyroxenes. Am Mineral 73: 1123-1133

Ozdín D, Uher P (2002) Slovenské názvy minerálov. Minerály schválené Medzinárodnou mineralogickou asociáciou do konca roku 2001. ŠGÚDŠ, Bratislava, 1-203

PAPP K V (1915) A Magyar birodalom vasérc és köszénkészlete. A Fraklin-társulat nyomdája, Budapest, $964 \mathrm{~s}$

Pecho J, Beñka J, Gargulák M, Václav J (1981) Geologický výskum antimonitových ložísk v oblasti Betliar - Čučma - Volovec. Čiastková záverečná správa. MS, Geofond - archív ŠGÚDŠ, Bratislava, 439 s

PetereC D, ĎuĎA R (2003) Zriedkavé minerály Mn ložiska pri Čučme. Natura Carpatica 44: 229-236

Peterec D, ĎuďA R (2009) Mangánová mineralizácia na lokalite Čučma. Minerál 17, 5: 410-414

Putiš M, Sergeev S, Ondrejka M, Larionov A, Siman P, SPIŠIAK J, UHER P, PADERIN I (2008) Cambrian-Ordovician metaigneous rocks associated with Cadomian fragments in the West-Carpathian basement dated by SHRIMP on zircons: a record the Gondwana active margin setting. Geol Carpath 59: 3-18

Radvanec M, Grecula P (2016) Geotectonic and metallogenetic evolution of Gemericum (Inner Western Carpathians) from Ordovician to Jurassic. Miner Slov 48, 2: $105-118$
Radvanec M, Konečný P, Németh Z, Grecula P (2007) P-T-t dráha a lokálne anatektické tavenie metapelitu s prímesou psamitickeho kremeňa vo variskej metamorfóze gemerika. Miner Slov 39, 1: 1-44

Radvanec M, Konečný P, Ondrejka M, Putiš M, Uher P, NÉMETH Z (2009) Granity gemerika ako indikátor extenzie kôry nad neskorovariskou subdukčnou zónou a pri ranoalpínskej riftogenéze (Západné Karpaty): interpretácia podla veku monazitu a zirkónu datovaného metódou CHIME a SHRIMP. Miner Slov 41, 4: 381-394

RoJkovič I (1999) Manganese mineralization in the Western Carpathians, Slovakia. Geol Carpath spec iss 50: 191-192

RoJkovıč I (2000) Mineralogická charakteristika mangánových rúd Slovenska. Príloha záverečnej správy Metalogenetické hodnotenie územia Slovenskej republiky. MS, Geofond - archív ŠGÚDŠ, Bratislava, $158 \mathrm{~s}$

RoJkovič I (2001) Early Paleozoic manganese ores in the Gemericum Superunit, Western Carpathians, Slovakia. Geolines 13: 34-41

RozıožNí O (1973) Prehl'ad geologických a ložiskových pomerov okolia Rožňavy. In: Labancz Š (ed.), Banícky Gemer, 70 rokov baníckeho múzea v Rožňave, 105126

SASSI R, VozÁROVÁ A (1987) The pressure character of the Hercynian metamorphism in the Gemericum (West Carpathians, Czechoslovakia). Rend Soc Ital Min Petr 42: 73-81

SASSI R, VozÁROVÁ A (1992) Pressure character of the Variscan metamorphism in the Gemericum and Veporicum (West Carpathians; Czecho-Slovakia). Boli Soc Geol It 111: 33-39

SchafARzIK F (1904) Adatok a szepes-gömöri érczhegység pontosabb geologiai ismeretéhez. Matematikai és természettudományi értesítő. Akadémia, Budapest, 22: 414-447

Schultz-Güttler R, Peters TJ (1987) Coexisting rhodonite and pyroxmangite in the system $\mathrm{MnSiO}_{3}-\mathrm{CaSiO}$ ${ }_{3}-\mathrm{MgSiO}_{3}-\mathrm{FeSiO}_{3}$ as a geothermometer. Schweiz Mineral Petrogr Mitt 67: 47-51

SiIVolA J, SCHMID R (2007) List of mineral abbreviations. In: Fettes D, Desmons J (eds.): Metamorphic rocks. A Classification and Glossary of Terms. Recommendations of the International Union of Geological Sciences. Subcommision on the Systematics of Metamorphic Rocks. Cambridge University Press, 93-110

SNOPKO L (1967) Litologická charakteristika gelnickej série. Sbor Geol Vied ZK 7: 103-152

SNOPKOVÁ P, SNOPKO L (1979) Biostratigrafia gelnickej série $v$ Spišsko-gemerskom rudohorí na základe palinologických výsledkov (Západné Karpaty, paleozoikum). Západ Karpaty sér geol 5: 57-102

SotÁK J, VozÁRovÁ A, IVANIČKA J (1999) New microfossils from the Early Paleozoic formation of the Gemericum (Foraminiferida). Special Issue from the Geol. Conf. Carpathian Geology 2000 in Smolenice. Geol Carpath 50: $72-74$

SotÁk J, VozÁRová A, IVANIČKa J (2000) A new microfossils from the Early Paleozoic formations of the Gemericum. Slovak Geol Mag 6, 2-3: 275-277

SPIŠIAK J, HovorKa D, RYBKA R, TURAN J (1989) Spessartín a piemontit $v$ metasedimentoch staršieho paleozoika vnútorných Západných Karpát. Čas Mineral Geol 34, 1: $17-29$ 
Števko M, Plecháček J, Venclík V, Malíková R (2015) Hausmannit a manganosit z mangánového ložiska Čučma-Čierna baňa (Slovenská republika). Bull mineral-petrolog Odd Nár Muz Praha, 23, 1: 39-42

То́тн M (1882) Magyarország ásványai. Különös tekintettel termőhelyeik megállapítására. Budapest, $509 \mathrm{~s}$

VARČEK C (1963) Vzt’ahy ložiskotvorných procesov v Západných Karpatoch ku ich geologickému vývoju. Acta geol Univ Comen Geol 8: 7-37

Vassileva R D, Grozdev V, Peytcheva I, Machev P, von QUADT A (2018) Grossulars from the skarnified marbles of the Chepinska Unit, Western Rhodopes. Proceedings of National Conference with international participation "GEOSCIENCES 2018" 35-36

VÁŽNA L, IVANIČKA J, SNOPKO L (1986) Predbežné výsledky petrografického a geochemického štúdia karbonátov gelnickej skupiny. Spr o výsk GúDŠ, Reg geol Záp Karpát 21: 55-58

VoZÁROVÁA (1993) Variská metamorfóza a krustálny vývoj v gemeriku. Západ Karpaty sér miner petrogr geochém metalogen 16: 55-117

VozÁROVÁ A (1998) Hercynian development of the external-Gemeric zone. In: Rakús M. (ed.): Geodynamic development of the Western Carpathians. Geological Survey of Slovak republic, Bratislava, 47-61
VozÁrová A, SOTÁK J, IVANIČKA J (1998) A new microfauna from the Early Paleozoic formations of the Gemericum (foraminifera): constrains for other fossils or subfossils. In: Rakús M. (ed.): Geodynamic development of the Western Carpathians. Geological Survey of Slovak republic, Bratislava, 63-74

VozÁRovÁ A, SotÁK J, IVANIČKA J (1999) Cambro-Ordovician fossils (conodontes, foraminiferes, chitinous shields) from the metamorphic series of the Gemericum (Western Carpathians). Jour Confer Abstr EUG 10 Vol 4, No 1, p. 266

Vozárová A, Šarinová K, Larionov A, Presnyakov S, SerGEEV S (2010) Late Cambrian/Ordovician magmatic arc type volcanism in the Southern Gemericum basement, Western Carpathians, Slovakia: U-Pb (SHRIMP) data from zircons. Int J Earth Sci (Geol Rundsch) 99, 1: 17-37

Vozárová A, Rodionov N, Šarinová K, Presnyakov S (2016) New zircon ages on the Cambrian-Ordovician volcanism of the Southern Gemericum basement (Western Carpathians, Slovakia): SHRIMP dating, geochemistry and provenance. Int J Earth Sci (Geol Rundsch) 106, 6: 2147-2170 